\title{
Health care for women over 50: programmatic vulnerability in the Family Health Strategy
}

\author{
Atenção à saúde da mulher após os 50 anos: vulnerabilidade \\ programática na Estratégia Saúde da Família \\ Atención a la salud de la mujer después de 50 años: la vulnerabilidad \\ programática de la Estratégia de Salud de la Família
}

\author{
Kelly Karine Pasqual ${ }^{a}$ \\ Maria Antonieta de Barros Leite Carvalhaes ${ }^{b}$ \\ Cristina Maria Garcia de Lima Paradac
}

D0l: $\quad$ http://dx.doi.org/10.1590/19831447.2015.02.44822

\footnotetext{
a Nurse. Secretaria Municipal de Saúde de Marilia. Master's degree student in Biology and Aging at the Faculdade de Medicina de Marília. Marília, São Paulo, Brazil.

- Professor Doctor. Faculdade de Medicina de Botucatu of the Universidade Estadual Paulista "Júlio de Mesquita Filho". Marília, São Paulo, Brazil.

'Adjunct Professor. Faculdade de Medicina de Botucatu of the Universidade Estadual Paulista "Júlio de Mesquita Filho". Marília, São Paulo, Brazil.
}

\section{ABSTRACT}

Objective: To assess the health care process for women over 50 at a Family Health Unit based on the concept of programmatic vulnerability.

Method: This study is inserted in the field of health care assessments. The framework proposed by Donabedian was used to analyze $90.5 \%$ of the 790 records of women registered at the unit.

Results: It was observed that none of the women that did not have a diagnosed pathology attended the recommended consultations or underwent the recommended tests. Of the total number of women with hypertension or diabetes, $20.7 \%$ were registered in the Hiperdia Programme and less than $1.0 \%$ had attended the consultations and undergone the necessary tests. Only $11.9 \%$ of the women had had a gynaecological examination, a clinical breast examination and a mammography the year before data collection. Conclusion: It is concluded that women over 50 are in a situation of programmatic vulnerability in terms of the indicators established in this study. Knowledge of this reality can help nurses provide care that is best suited for this group.

Keywords: Primary health care. Women's health. Program evaluation.

\section{RESUMO}

Objetivo: Avaliar o processo de atenção prestada a mulheres, a partir dos 50 anos de idade ${ }_{\perp}$ em Unidade de Saúde da Família, tomando-se como referência o conceito de vulnerabilidade programática.

Método: Estudo inserido no campo da avaliação de programas de saúde; utilizou-se o referencial proposto por Donabediam, sendo analisados 90.5\% dos 790 prontuários de mulheres matriculadas na Unidade.

Resultados: Observou-se que nenhuma mulher sem patologia diagnosticada realizou consultas e exames preconizados. Do total de hipertensas e diabéticas, 20.7\% estavam inscritas no Programa Hiperdia e menos de 1.0\% tinha realizado as consultas e exames necessários. Apenas $11.9 \%$ das mulheres tinham realizado exame ginecológico, exame clínico das mamas e mamografia no ano que antecedeu a coleta de dados.

Conclusão: Conclui-se que as mulheres com mais de 50 anos estão em situação de vulnerabilidade programática, relacionada aos indicadores definidos neste estudo. Logo, conhecer a realidade poderá resultar no atendimento de enfermagem mais adequado para esse grupo.

Palavras-chave: Atenção primária à saúde. Saúde da mulher. Avaliação de programas e projetos de saúde.

\section{RESUMEN}

Objetivo: evaluar el proceso de atención a las mujeres a partir de los 50 años de edad en la Unidad de Salud de la Familia, tomando como referencia el concepto de vulnerabilidad del programa.

Método: Estudio insertado en la evaluación de programas de salud, tuvo Donabediam como referencia, siendo analizados el 90,5\% de los 790 registros médicos de mujeres inscritas en la unidad. Fueran creados indicadores de evaluación.

Resultados: Ninguna mujer sin patología diagnosticada realizó consultas y exámenes recomendados. De todas las hipertensas y diabéticas, 20,7\% estaban inscritas en el Programa Hiperdia y menos del 1,.0\% había realizado consultas y exámenes necesarios. Sólo el 11.9\% de las mujeres había realizado el examen ginecológico, examen clínico de los senos y la mamografía en el año anterior a la recolección de datos.

Conclusión: Concluye que las mujeres mayores de 50 años están en situación de vulnerabilidad programática en relación con los indicadores definidos en este estudio. Por lo tanto, conocer la realidad puede resultar en la atención de enfermería más adecuada para este grupo.

Palabras clave: Atención primaria de salud. Salud de la mujer. Evaluación de programas y proyectos de salud. 


\section{DINTRODUCTION}

Until the 1970s, women's health care in Brazil focused on a biological vision with evident emphasis on pregnancy, childbirth and the postpartum period ${ }^{(1)}$. In 1984, with the creation of the Women's Comprehensive Care Programme (PAISM), the criteria of priorities seemed to expand to beyond the pregnancy-postpartum cycle and included women of other age groups.

As an evolution of the PAISM, the National Policy Plan for Women presented by the Brazilian Government in 2013 also targets improvements for the living conditions and health of women at all the stages of their lives. It also seeks to improve access to means and services for health promotion and prevention, and comprehensive care for women in Brazil, without any form of discrimination (2).

Despite efforts in the area of women's health, the national public policies mostly focus on the reproductive stages of women's lives. This priority creates a challenge for the expansion of care, especially in relation to menopause when, in addition to the evident changes, chronic and degenerative diseases commonly appear.

The widely used concept of vulnerability has been inserted in the area of health since the 1980s, when it was initially considered in studies about AIDS. In summary, studies of vulnerability seek to understand how individuals and groups of individuals are exposed to a given health condition based on pragmatically constructed syntheses of three analytic dimensions: individual, including biological, behavioural and affective aspects that lead to exposure and susceptibility to a given health condition; social, namely characteristics of socially configured contexts and relationships that overdetermine the programmatic aspects and that consider the way and sense in which technologies that are already operating in these contexts, such as policies, programmes, services and actions, interfere in a given situation ${ }^{(3)}$.

As a member of the Family Health team, the nurse must assist women during all the stages of their lives. The aim of this study is to support nurses and other women's health care professionals by assessing the process of care provided to women over 50 at the Family Health Unit (USF), based on the concepts of programmatic vulnerability.

\section{METHOD}

This descriptive and epidemiological study is inserted in the field of assessments of health care services, programmes or projects.
The adopted theoretical framework was proposed by Donabedian in the 1960s, and is still widely used due to its simplicity and usefulness ${ }^{(4)}$. When considering the process, the author proposes the evaluation of activities carried out by the service providers, and compares the employed procedures to established standards. In summary, the necessary procedures are identified and checked to determine whether they were correctly applied. Unnecessary procedures, which can be limited or abandoned, are identified to ensure the economy of resources and increased productivity.

This study was conducted in the municipality of Botucatu, in the south-central region of state of São Paulo, Brazil, with an estimated population in 2012 of 130,183 inhabitants, of which approximately 67,000 were women ${ }^{(5)}$. The USF elected for this study is located on the outskirts of this municipality.

Of the 790 women aged 50 or over registered at this unit in 2011, 715 were included in the study (90.5\%). The other individuals were excluded due to change of address to other municipalities (74 cases), blank medical files (29 cases) and death (one case).

To characterize the selected women, social variables, such as schooling, marital status and age were analyzed. Further analysis considered procedures performed from January to December 2010 and three additional aspects, namely disease prevention, health promotion, gynaecological care, and care for chronic diseases.

To assess preventive measures and health promotion, data were collected on medical or nursing consultations (yes/no), type of consultation (scheduled/one-off/both), simultaneous use of a private service and/or health insurance (yes/no), and participation in an educational group activity (yes/no). In the area of gynaecology, the investigated topics were gynaecological examination (yes/no), clinical breast examination (yes/no), mammography (yes/ no); direct Gram stained vaginal smear (yes/no), cure control based on the results of the Gram stained vaginal smear, when indicated (yes/no), and Pap smears (yes/no). With regard to chronic diseases and considering the specific programme for this purpose (HiperDia), the investigated topics were care for arterial hypertension and diabetes based on the variables of diagnosis of hypertension and/or diabetes (yes/no), register in the programme (yes/no), and continued use of medication (yes/no). Additional assessments included recommended tests for women without a pathology, women with hypertension and women with diabetes, namely electrocardiogram, total cholesterol and fractionation, triglycerides, urea, creatinine, fasting blood sugar, complete blood count, potassium and urine (yes/ 
no). For the diabetic women, testing for glycosylated haemoglobin (yes/no) was also assessed.

In the absence of national indicators to assess the quality of care for women in the studied age group, the public municipal policy ${ }^{(6)}$ was used as a basis for the summary indicators. This policy was created according to the National Policy for Women's Health ${ }^{(2)}$ and the National Policy of Elderly People and Aging ${ }^{(7)}$. The summary indicators are:

Proportion of women without a pathology, but with routine and recommended follow-up at the USF, namely a medical or nursing consultation, and an annual electrocardiogram and laboratory tests.

Proportion of women with hypertension registered at the HiperDia Programme with the recommended follow-up, namely a minimum of one doctor's appointment and a nursing consultation per year, and an annual electrocardiogram and laboratory tests.

Proportion of women with diabetes registered at the HiperDia Programme with the recommended follow-up, namely a minimum of one doctor's appointment and a nursing consultation per year, and an annual electrocardiogram and laboratory tests.

Proportion of women who underwent a medical breast examination, a gynaecological examination and a mammography in the 12 months prior to data collection.

For data collection, the main author consulted the medical records of the women and used an instrument that was especially created for this study. After collection, the data were checked, encoded, entered into an Excel spreadsheet, and subsequently analyzed in the Epi Info 6.0 programme. File consistency was checked by comparing the distribution of frequencies in associated issues, with correction of any identified errors.

This research project was approved by the local Research Ethics Committee (Of. 320/2010), and complies with all the standards for research with human beings.

\section{口 RESULTS}

A brief characterization of the women indicated an age range from 50 to 98 years, being that most of the women were over 64 (61.7\%). The majority of these women had not finished primary school (52.0\%) and were married or in a stable relationship (56.4\%).

The vast majority of women had attended a medical and/or nursing appointment at the public health care service in the year preceding data collection (81.9\%), and $13.7 \%$ of these women had only had a one-off consultation. A quarter of the women had used private services and/or health insurance together with the family health care service. Only $11.2 \%$ of the women had participated in educational group activities (Table 1).

In the area of gynaecology, $16.5 \%$ had had a gynaecological consultation, $20.7 \%$ had undergone a clinical breast examination, and $16.8 \%$ had had a mammography. Of the women over $64,35.1 \%$ had had a Pap smear, $13.4 \%$ had had a direct Gram stained vaginal smear, and among the women with exam results that showed some alteration, almost half (47.8\%) completed cure control after treatment (Table 1). In 284 of the studied records, (39.7\%), there were no Pap smear results, regardless of the collection date, which shows that this test had never been performed at the health care unit. The last test results on record were three atypical squamous cell results of an undetermined significance, one case of high-level lesions and a case of adenocarcinoma in situ, being that four of these five cases had occurred in women over 64 (data not shown in the table).

In relation to chronic diseases, most women had a diagnosis of hypertension and/or diabetes (70.1\%), with a predominance of cases of hypertension (53.7\%) in comparison to diabetes (24.2\%). Of the women with hypertension and diabetes, only one fifth (104 women or 20.7\%) were registered at the HiperDia Programme, which is a governmental initiative to monitor these two chronic diseases (Table 1).

The tests conducted on the women without a pathology and on the women with hypertension and diabetes are shown in Table 2.

Whilst the Botucatu women's care protocol indicates the realization of an annual routine electrocardiogram, coverage was varied: $3.3 \%$ among those who had no pathology, $12.0 \%$ for women with hypertension and $15.6 \%$ for women with diabetes. Among the women with hypertension, coverage of the total cholesterol and fractionation tests was $50.5 \%$, and it was the most frequently performed test. Among the diabetic women, 55.5\% underwent fasting blood sugar tests and total cholesterol and fractionation tests. Among the women with no pathology, the most frequent tests were total cholesterol and fractionation, triglycerides, complete blood count and fasting blood sugar, each of which was conducted on $8.9 \%$ of the women. Less than $1.0 \%$ of women took the recommended set of tests (Table 2).

Table 3 shows the created summary indicators.

None of the women without a pathology received the recommended routine care. The protocol, provided by the HiperDia Programme for women with hypertension and diabetes, was followed by less than $1.0 \%$ of the women, and $11.9 \%$ received the indicated routine gynaecological care (Table 3). 
Table 1 - Variables related to the care process of women over 50. Botucatu, 2013

\begin{tabular}{|c|c|c|}
\hline Variables & $\mathbf{N}$ & $\%$ \\
\hline Medical and/or nursing consultation $(n=715)$ & 586 & 81.9 \\
\hline \multicolumn{3}{|l|}{ Type of consultation $(n=557)$} \\
\hline Scheduled & 189 & 33.9 \\
\hline One-off & 76 & 13.7 \\
\hline Scheduled and one-off & 292 & 52.4 \\
\hline Participation in educational group $(n=715)$ & 80 & 11.2 \\
\hline Home visit $(n=715)$ & 70 & 9.8 \\
\hline Private service/health insurance $(n=715)$ & 184 & 25.7 \\
\hline Gynaecological medical examination $(n=715)$ & 118 & 16.5 \\
\hline Clinical breast examination $(n=715)$ & 148 & 20.7 \\
\hline Mammography $(n=715)$ & 120 & 16.8 \\
\hline Pap smear, 64 or under $(n=441)$ & 155 & 35.1 \\
\hline Direct vaginal smear $(n=715)$ & 96 & 13.4 \\
\hline Cure control for altered direct examination $(n=46)$ & 22 & 47.8 \\
\hline Diagnosis of hypertension and/or diabetes $(n=715)$ & 501 & 70.1 \\
\hline Diagnosis of hypertension $(n=715)$ & 384 & 53.7 \\
\hline Diagnosis of diabetes $(n=715)$ & 173 & 24.2 \\
\hline Registered at HiperDia $(n=501)$ & 104 & 20.7 \\
\hline Continued use of medication $(n=715)$ & 488 & 68.3 \\
\hline
\end{tabular}

Source: Research data, 2013.

Table 2 - Recommended tests performed on women without a pathology, with hypertension or with diabetes, in the year prior to data collection. Botucatu, 2013

\begin{tabular}{lcccccc} 
& \multicolumn{2}{c}{$\begin{array}{c}\text { No Pathology } \\
\mathbf{n = 9 0}\end{array}$} & \multicolumn{2}{c}{$\begin{array}{c}\text { Hypertension } \\
\mathbf{n = 3 8 4}\end{array}$} & \multicolumn{2}{c}{$\begin{array}{c}\text { Diabetes } \\
\mathbf{n = 1 7 3}\end{array}$} \\
\cline { 2 - 7 } & $\mathbf{N}$ & $\mathbf{\%}$ & $\mathbf{N}$ & $\mathbf{\%}$ & $\mathbf{N}$ & $\mathbf{\%}$ \\
\hline Electrocardiogram & 3 & 3.3 & 46 & 12.0 & 27 & 15.6 \\
Cholesterol & 8 & 8.9 & 194 & 50.5 & 96 & 55.5 \\
Triglycerides & 8 & 8.9 & 174 & 45.3 & 88 & 50.9 \\
Urea & 5 & 5.6 & 172 & 44.8 & 82 & 47.4 \\
Creatinine & 5 & 5.6 & 182 & 47.4 & 91 & 52.6 \\
Fasting blood sugar & 8 & 8.9 & 192 & 50.0 & 96 & 55.5 \\
Glycosylated haemoglobin & - & - & - & - & 55 & 31.8 \\
CBC & 8 & 8.9 & 114 & 29.7 & 50 & 28.9 \\
Potassium & 1 & 1.1 & 28 & 7.3 & 11 & 6.4 \\
Urine & 5 & 5.6 & 152 & 39.6 & 80 & 46.2 \\
All tests & 0 & 0.0 & 3 & 0.8 & 1 & 0.6 \\
\hline
\end{tabular}

Source: Research data, 2013. 
Table 3 - Summary indicators for evaluating the quality of care for women over 50. Botucatu, 2013

\begin{tabular}{lcc}
\multicolumn{1}{c}{ Summary Indicators } & N & \% \\
Clinical breast examination, gynaecological examination and mammography & 85 & 11.9 \\
Women with hypertension registered at the HiperDia and recommended follow-up & 3 & 0.8 \\
Women with diabetes registered at the HiperDia and recommended follow-up & 1 & 0.6 \\
Absence of pathology and routine follow-up at the Unit & 0.0 \\
\hline
\end{tabular}

Source: Research data, 2013

\section{DISCUSSION}

In addition to assessing the quality of care for women over 50 at the family health care unit, this study led to the creation of indicators that can be used in other locations and at a national level to assess whether the observed scenario is a local problem or if, as suspected, the detected problems are widespread. It should be noted that the indicators to detect the quality of women's primary health care in the studied age group are not available in the Brazilian programmes, policies and information systems, despite recent efforts to include them ${ }^{(2)}$.

An important methodological aspect to be considered in the interpretation of these results is the fact that the data were obtained from medical records, since registration deficiencies may have led to some underestimation of the actions taken. However, numerous Brazilian evaluative studies are based on data from medical records ${ }^{(8-9)}$.

The analysis of the care process, which is the main focus of this study, highlights various aspects of programmatic vulnerability. In the work process of primary care teams, especially those that adopt the family health strategy, collective community actions and group activities are some of the essential resources for the provision of quality care. However, the participation of women in these types of actions/activities was very limited. Only 11.2\% of the women said they participate in educational groups, which could have helped to establish a bond that complements individual consultation and enables the exchanging of information and the provision of guidance and health education. Thus, this strategy should be further considered by the managers and staff at the USF in order to ensure it is more effectively and reflexively employed.

It was observed that most of the women had had oneoff consultations (66.1\%), and some had exclusively sought this type of care. This reveals some carelessness with the promotion of health, since one-off consultations are characterized by the presence of complaints that justify care and the correct conduct of medical professionals to solve or minimize these complaints until programmatic care is full provided, with all the related preventive and health care promotion actions. Whilst one fourth of the women also received care from a private service, the characteristics of these services in the municipality imply that the offered health care promotion actions are even more limited.

Home visits, with the exclusion of visitations from community health care agents, were rare events and were only reported for less than $10.0 \%$ of the women. Home visits should be planned by the team in order to address the specific needs of users. They are offered to support intervention in the health-sickness process of individuals or for the planning of actions that promote collective health $(7,10)$. Once again, this type of action was not a priority with regard to families with women over 50.

Hypertension and diabetes were frequently identified pathologies. However, only two out of every 10 women with hypertension and/or diabetes were registered at the HiperDia. Chronic diseases, such as those mentioned above, have gradually increased in Brazil in the over-40s population, and frequently result in complications and early retirement ${ }^{(11)}$. To counterbalance the lack of regular monitoring, the continued use of medication was very frequent (68.3\%). In Brazil, an estimated 35\% of drugs are self-administered, which accounts for $27 \%$ of intoxications and $16 \%$ of deaths caused by drug-related intoxications. Furthermore, $50 \%$ of all medication is prescribed, sold or used inappropriately $^{(12)}$.

Whilst this study design did not assess whether medication was prescribed or sold correctly, use of medication did not seem excessive, since $70.1 \%$ of the women had diagnosed hypertension and diabetes that often require this type of treatment. However, considering the low coverage of programmatic consultations, it can be assumed that many drugs are used without regular monitoring.

In the area of gynaecology, the situation was far from ideal although better indicators were expected in this area given the traditional priority this type of care is given at the primary care units in relation to women's health. Pap smear coverage during the year preceding data collection was low even in the priority age range (64 or under). Almost 40\% of 
women had no record of smear tests, suggesting the possibility that in the primary care unit of reference where the study was conducted, cytological samples were not collected. This is especially relevant since the test is simple, cheap, non-invasive and highly accurate. This also reveals that the USF must take action to change this picture.

In addition to the problem of coverage, results analysis of the last tests found two alterations and three possible alterations. Although the two cases with alterations were referred for treatment, additional tests were not scheduled for all of the suspected cases. The medical records did not contain any reference to treatment and follow-up of cases, although the women were still receiving care at the USF for other health problems. Another noteworthy aspect is that four of the five women with cytological alterations or suspicion of alterations were above the priority age range and may not have been tested, which reveals another aspect of programmatic vulnerability.

Data related to gynaecological cancer prevention indicate faults in relation to the comprehensiveness of the provided care. A qualitative study on cervical cancer conducted in southern Brazil showed that the provision of comprehensive care for women implies the acknowledgment of an action-based logic that considers their individual and collective needs within their social context ${ }^{(13)}$, which could be favoured at the studied family health care units. In this sense, actions that seek to expand coverage and follow-up should be implemented. This includes the active pursuit of women who have never had Pap smears and who fail to appear at medical appointments. Strategies that guarantee referrals and counter-referrals when necessary should also be implemented.

Considering that one of the main complaints in gynaecology outpatient units is vaginal discharge, the studied unit deployed the routine collection of Gram stained vaginal smears in 2010. However, the coverage of this test was very low (13.4\%) and cure control, which should be initiated 40 days after the end of treatment, occurred in less than half of the cases that required this control.

Results of the care assessment summary, in all the analyzed aspects, were alarming and showed a total discrepancy with the municipal policy of women's health(6). Familiarity with these aspects is the first step for health care teams in general, and specifically for nursing teams, to review their planning in order to implement actions that can comprehensively improve the care offered to women over 50.

In the area of gynaecology, only one in 10 women had had breast examinations, a medical gynaecological examination and a mammography in the year preceding data collection. This unfavourable situation for the detection of breast cancer is maintained, although this is the most feared type of neoplasia among women due to the high frequency rates and the associated emotional effects that affect their perception of sexuality and their self image. The Southeast region of Brazil has the highest incidence and ranks first in cancer mortality rates among women. It is unquestionable that health care units must include actions that enable early detection and the appropriate treatment for cancer. According to criteria of the Brazilian Ministry of Health ${ }^{(14)}$, women in the low risk group and women in the 50 to 69 age group should be tested at least every two years; however, according to the municipal policy ${ }^{(6)}$, these tests should be annual. Thus, the scarce evidence of mammographies reveals the level of personal and programmatic vulnerability to which these women are exposed.

The process summary indicators proposed in this study related to hypertension and diabetes show that, although the individual analysis of consultations and/or recommended testing was reasonable, the set of recommended actions was poorly observed and only provided to less than $1 \%$ of the studied women. The USF should effectively implement the HiperDia Programme and include all the actions that will enforce the adoption of a healthy lifestyle, since excess weight, an inadequate diet, and a sedentary lifestyle contribute to the appearance of complications related to chronic illnesses ${ }^{(15)}$.

The municipal policy also includes the proposal of routine annual care for healthy adults from the age of $40^{(6)}$. However, none of the studied women had had the recommended consultations or tests. The fact that natural aging should not be treated as a disease is widely acknowledged, and unnecessary tests and treatment due to the signs and symptoms that can be easily explained by senescence should be avoided. However, not all alterations that occur at this stage of life are the result of natural aging, and regular checkups ensure the prevention, early detection and treatment of complications ${ }^{(1)}$.

Consequently, the care process for women must be reviewed, from the education of future workers to the training of those who are already inserted in the practice field. The debate on the health of women aged 50 or over must be introduced in intersectoral actions and the different social equipment, whether institutionalized or not. Such an approach must be demystified and seen as a close reality, given the current epidemiological profile of Brazil. All management and workers who directly provide care must be committed to the proposal of the National Policy Plan for Women ${ }^{(2)}$, and must continuously seek to empower women to actively participate in changing their own realities. 


\section{FINAL CONSIDERATIONS}

The analysis of patient records revealed a predominance of one-off consultations and appointments for a large number of the studied women, and a low frequency of educational group activities. When the set of activities proposed in the care process was observed, the situation was especially negative, both for women with hypertension and diabetes, and for those who did not have a disease or complication. In the case of gynaecological care, there was a very low frequency of recommended consultations and testing among the studied women during the year that preceded data collection.

In the different studied aspects, the situation revealed the programmatic vulnerability to which women over 50 are exposed. It is therefore the responsibility of all those who directly or indirectly provide primary care to acknowledge the need for permanent education in order to promote inclusive and humanized care with a high rate of solvability. In summary, the involvement of both management and the health care teams is required to overcome the detected vulnerability.

\section{REFERENCES}

1. Freitas GL, Vasconcelos CTM, Moura ERF, Pinheiro AKB. Discutindo a política de atenção à saúde da mulher no contexto da promoção da saúde. Rev Eletr Enf [Internet]. 2009 [Access on: 10 apr 2012];11(2):424-8. Available at: http://www. fen.ufg.br/revista/v11/n2/v11n2a26.htm.

2. Presidência da República (BR). Plano Nacional de Política para as Mulheres [Internet]. Brasília (DF): Secretaria Especial de Política para Mulheres; 2013 [Access on: 14 dec 2013]. Available at: http://www.compromissoeatitude.org.br/wp-content/uploads/2012/08/SPM_PNPM_2013.pdf

3. Ayres JRCM. Organização das açōes de atenção à saúde: modelos e práticas. Saúde Soc. 2009;18 Supl 2:11-22.

4. Donabedian A. The quality of care: how can it be assessed? J Am Med Assoc. 1988;260(12):1743-8
5. Fundação Sistema Estadual de Análise de Dados [Internet]. São Paulo: SEADE; 2013 [Access on: 10 jan 2013]. Available at: www.seade.gov.br/produtos/perfil/perfilMunEstado.php.

6. Botucatu (SP). Protocolo de Enfermagem. Botucatu: Secretaria Municipal de Saúde; 2007.

7. Ministério da Saúde (BR). Secretaria de Atenção à Saúde. Departamento de Ações Programáticas e Estratégicas. Atenção à saúde da pessoa idosa e enveIhecimento [Internet]. Brasilia: Ministério da Saúde; 2010 [Access on: 10 dec 2013]. Available at: http://bvsms.saude.gov.br/bvs/publicacoes/atencao_saude_pesso__idosa_envelhecimento_v12.pdf

8. Souza CC, Toledo AD, Tadeu LFR, Chianca TCM. Risk classification in an emergency room: agreement level between a Brazilian institutional and the Manchester Protocol. Rev Latino-Am Enfermagem [Internet]. 2011 [Access on: 17 jan 2013];19(1):26-33. Available at: http://www.scielo.br/pdf/rlae/v19n1/05.pdf

9. Quadrado ERS, Tronchin DMR. Evaluation of the identification protocol for newborns in a private hospital. Rev Latino-Am. Enfermagem [Internet]. 2012 [Access on: 17 jan 2013];20(4):659-67. Available at: www.scielo.br/scielo.php?script=sci_ arttext\&pid=S0104-11692012000400005\& lng=en\&nrm=iso\&tlng=en

10. Albuquerque ABB, Bosi MLM. Visita domiciliar no âmbito da Estratégia Saúde da Família: percepções de usuários no município de Fortaleza, Ceará, Brasil. Cad Saúde Pública [Internet]. 2009 [Access on: 11 apr 2012];25(5):1103-12. Available at: http://www.scielo.br/scielo.php?script=sci_arttext\&pid=\$0102$-311 \times 2009000500017 \& \mid n g=p t \&$ nrm=iso

11. Instituto de Pesquisa Econômica e Aplicada. Comunicado da Presidência. Qualidade de vida: seus determinantes e sua influência sobre a seguridade social [Internet]. 2009 [Access on: 10 apr 2012]. Available at: http://www.ipea.gov. br/portal/images/stories/PDFs/comunicado/091014_comunicadoipea33.pdf

12. Aquino DS. Por que o uso racional de medicamentos deve ser uma prioridade? Ciênc Saúde Colet. 2008;13(Supl):733-6.

13. Soares MC, Mishima SM, Silva RC, Ribeiro CV, Meincke SMK, Corrêa ACL. Câncer de colo uterino: atenção integral à mulher nos serviços de saúde. Rev Gaúcha Enferm. 2011;32(3):502-8.

14. Instituto Nacional do Câncer (BR). Programa Nacional de Controle do Câncer de Mama [Internet]. Rio de Janeiro (RJ): Instituto Nacional do Câncer; 2010 [Access on: 10 dec 2013]. Available at: http://www2.inca.gov.br/wps/wcm/connect/ fad72d004eb684b68b379bf11fae00ee/pncc_mama.pdf?MOD=AJPERES\&CA CHEID=fad72d004eb684b68b379bf11fae00ee

15. Schmidt MI, Duncan BB, Silva GA, Menezes AM, Monteiro CA, Barreto SM et al. Chronic non-communicable diseases in Brazil: burden and current challenges. The Lancet. 2011;377(9781):1949-61. doi: 10.1016/50140-6736(11)60135-9.
Author's address:

Cristina Maria Garcia de Lima Parada

Campus Universitário de Rubião Jr, s/n, Rubião Jr

18618-970 Botucatu - SP

E-mail: cparada@fmb.unesp.br
Received: 27.01.2014

Approved: 17.04.2015 